\title{
THE ANALYSIS OF INFLUENCING FACTORS OF OFFERING RICE PRICE IN SERDANG BEDAGAI REGENCY
}

\author{
Esty Surya Ramadhani ${ }^{* 1}$, Muhammad Yusuf $^{2}$ \\ 1*) Postgraduate Program, Universitas Negeri Medan \\ ${ }^{2}$ Faculty of Economics, Universitas Negeri Medan \\ Email: estyramadhani@yahoo.com
}

\begin{abstract}
The world's back is concerned with food security issues for the community, pecially from the dimensions of availability, access to food and food price stability. Countries should be able to increase production in order to provide food rice sufficiency and sustainable, but on the other hand there are many factors that affect the level of availability of rice in the community. This study aimed to analyze the influence of the harvested area, the price of rice, the price of bread, and rainfall to supply rice in Serdang Bedagai. In measuring and analyzing regression analysis model was used Ordinary Least Square (OLS) with a data processor Eviews 6.0. By using secunder data from BPS Serdang Bedagai during the period 2011 - 2015. The results showed that the independent variables used to explain the variables rice deals $(P B)$ indicate the direction of influence in accordance with the hypothesis. Area harvested and the price of rice positive and significant impact on rice deals (PB) while the price of bread and rainfall positive effect but not significant to supply rice (PB) in Serdang Bedagai Regency, North Sumatra Province.
\end{abstract}

Key words: Special, Harvested Area, Rice Price, Price Bread, Rainfall

\section{INTRODUCTION}

ice is a very unique commodity because from time to time it must be actively
managed with government agencies. Since the Dutch colonial era, the
Japanese population, and the war for independence, the Old Order, the New Order, and the Reformation Order to the current era of globalization, rice has remained the government's main concern among the nine staples (sembako). The issue of rice is an integral part of the social, economic and even political aspects of the Indonesian nation. One of the important things in the national rice system is knowing the level of supply and demand so that there is no scarcity or surplus of rice on the market which in turn is detrimental to the community as consumers and farmers as rice producers. At the desired level, rice prices that are reasonable and affordable for the community will be achieved and benefit farmers as producers. Considering the role of rice as the main food commodity of Indonesian society, achieving adequate national rice production is very important as one of the factors that influence the realization of national food security (Akbar, 2002). Regarding the issue of food, the world is again worried about the issue of food security for the people, especially in terms of availability, access to food 
and food price stability, considering that the phenomenon of climate change cannot be fully anticipated properly. When viewed from the aspect of consumption, the realization of food security also faces obstacles because most Indonesians have so far fulfilled their food needs as a source of carbohydrates in the form of rice. North Sumatra Province is an area that has considerable agricultural potential and serves as food storage in the West Sumatra region. This is because agro-climate, natural and cultural resources and the people mostly work in the agricultural sector, especially food crops. Apart from its very strategic geographical location, the province of North Sumatra is one of the potential locations for marketing agricultural products. However, food security for the province of North Sumatra is still an important issue. Since the 1980s, North Sumatra Province has become a food self-sufficient area. The status of food self-sufficiency is difficult to maintain because of a decline in production. Some of the causes that give rise to this weak food security start from mistakes in the management of agricultural lands to the lack of availability of various existing production facilities. Agricultural land management problems are relatively difficult problems to handle. This is because land is a limited production factor, which does not have the potential to support agricultural production if it is not managed by humans. In addition, agricultural land is no longer an important factor in production, given that agricultural land is decreasing in size as a result of land conversion from agriculture to non-agriculture (oil palm plantations). One of the rice centers in the province of North Sumatra is Serdang Bedagai Regency with a raw area of 40,598 hectares of rice fields, 70,000 - 75,000 hectares of Serdang Bedagai planting area per year with an average productivity of 5.2 tons / ha, Serdang Bedagai contributes to the availability of food in North Sumatra, with rice self-sufficiency averaging $125,000-135,000$ tons per year.

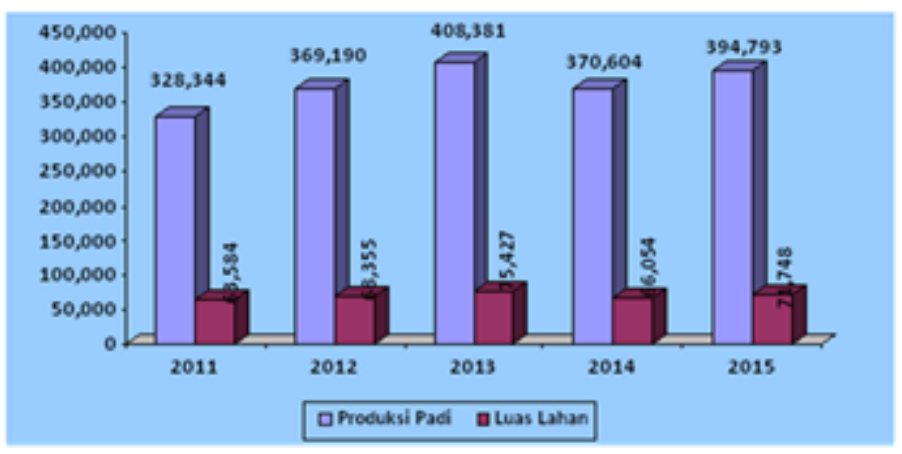

Figure 1: Rice Production and Harvested Area in Serdang Bedagai Regency 2012-2015 Source: Statistics Indonesia, Serdang Bedagai Regency in 2013-2016 figures

Figure 1 shows that in 2011 the harvested area was 63,584 hectares with a production of 328,344 tons. In 2012 and 2013 the rice harvested area increased to 68,355 hectares with a production of 369,190 tons in 2012 and in 2013 the harvested area for rice was 75,427 hectares with a production of 408,381 tons. However, in 2014 the rice harvested area experienced a decline, one of which was due to the conversion of land functions from agricultural land to non-agricultural land. The impact is that the harvested area is reduced to an area of 66,054 $\mathrm{Ha}$. The reduced harvest area will result in a decrease in rice production to 370,604 tons. 
With the reopening of agricultural lands that were previously non-productive land to agricultural land so that the agricultural land area increased which resulted in an increase in the area of rice harvest, it was recorded that in 2015 the area of paddy land was $71,748 \mathrm{Ha}$. This condition caused rice production to also increase to 394,793 tons. According to Swastika et al (2000), one of the causes of the fluctuation of rice production is the ongoing conversion of agricultural land to housing which has resulted in decreased rice supply. The rate of land conversion cannot be reduced, this is due to the government policy to urbanize the population who will use agricultural land to become residential land. In addition, the increasing need for land for housing and economic activities has had a negative impact on agricultural land. The area of land that was originally agricultural land will decrease along with the population growth rate and the progress of the economy. Business centers such as offices, shop houses, markets and so on as a means of economic activity will really need land as a medium for these activities. This condition is exacerbated by the large amount of land that is not used (non-productive) either as agricultural land or non-agricultural land, which is land owned by non-local residents. The result of diminishing agricultural lands will affect production in the agricultural sector, especially rice, which is the staple food bucket for the population.

Agricultural production cannot be separated from the influence of local natural conditions which is one of the factors supporting production. In addition to soil conditions suitable for certain crop conditions, climate also greatly determines whether an agricultural commodity is suitable for development in the area. (Soekartawi, 2002). The climate or weather observed in this study is rainfall which greatly affects rice production. Extreme rainfall causes crop production, especially rice, to be disrupted and even damaged (fuso). However, normal and not extreme rainfall will have a positive impact on the growth and development of agricultural crops, so a water system suitable for areas with extreme rainfall is needed.

The following is presented in a graph of the average rainfall during 2011 to 2015 in Serdang Bedagai Regency.

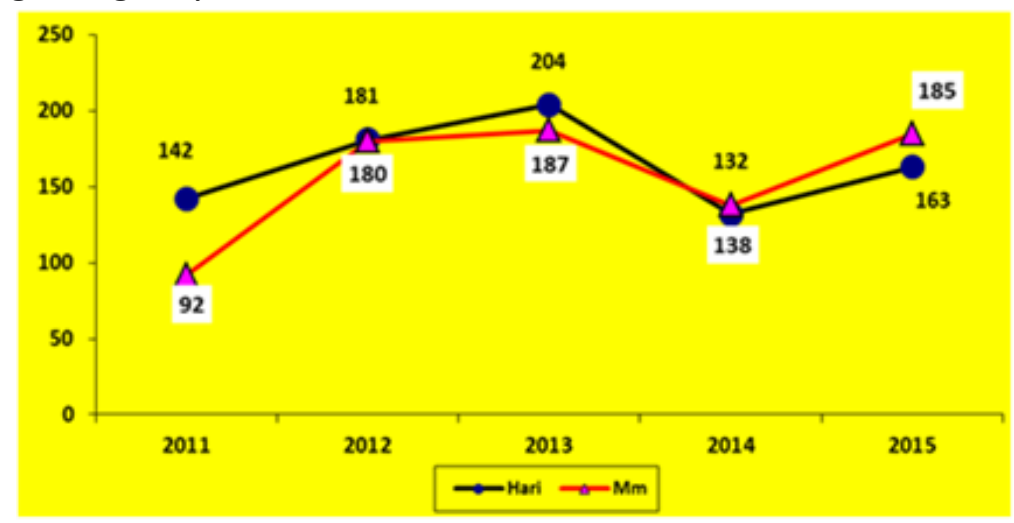

Figure 2: The Average Rainfall and Number of Rainy Days in Serdang Bedagai Regency 2012-2015

Source: Statistics Indonesia, Serdang Bedagai Regency in 2013-2016 figures 
Figure 2 shows the average rainfall and the number of rainy days in Serdang Bedagai Regency during 2011 - 2015, with the average rainfall in 2011 was $92 \mathrm{~mm}$ with 142 rainy days. In 2012 and 2013, the average rainfall increased to $180 \mathrm{~mm}$ with 181 rainy days in 2012, while in 2013, the average rainfall was $187 \mathrm{~mm}$ with 204 rainy days. Uncertain weather and climate conditions in recent years, one of which is rainfall. It was recorded that the average rainfall in 2014 decreased to $138 \mathrm{~mm}$ with 132 days of rainy days. Meanwhile in 2014, the average rainfall increased again to $163 \mathrm{~mm}$ with 195 days of rain.

The high intensity of rainfall will cause damage to agricultural land and plantations, not to mention changing seasonal patterns which cause changes in cropping patterns and harvest patterns that are usually implemented. In addition, climatic and weather conditions, especially rainfall, also play a role in affecting rice production. Extreme rainfall can disrupt and even damage rice production, but on the other hand, rainfall is also very helpful in the availability of water for rice plants so that rice production, which in this case is rice, will increase.

If observed, the rainfall that occurred in Serdang Bedagai Regency shows that the rainfall continued to increase, especially in the middle of 2015 which caused several agricultural areas to be disturbed and even damaged / fuso. Increased rainfall and poor irrigation systems were the main factors for the damage to agricultural crops, especially rice.

From the supply side of rice production, in this case rice production is strongly influenced by several other factors, such as the price of the goods themselves, production costs (fertilizer prices, labor prices), prices for substitutes (substitution), consumer tastes, and others. (Sukirno, 2005)

In this study, the substitute item for rice is plain bread, this is because white bread is not only practical in consuming it but also has important substances that are equivalent to rice, namely carbohydrates. As a substitute, the price of plain bread depends on the price of the basic goods, namely rice. The increase in rice prices will certainly affect the increase in the supply of substituted goods such as plain bread and vice versa.

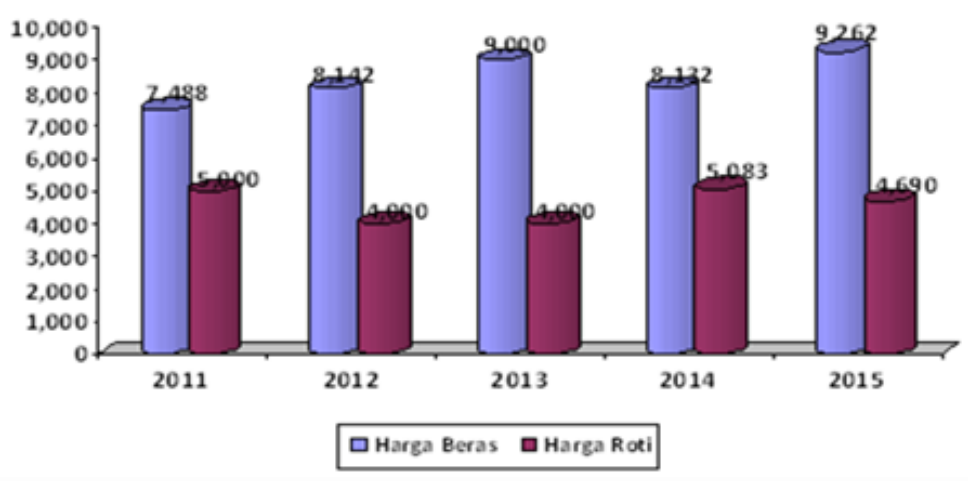

Figure 3: Rice Prices and Fresh Bread Prices in Serdang Bedagai Regency, 2012-2015 Source: Statistics Indonesia, Serdang Bedagai Regency in 2013-2016 figures 
The price of rice during 2011 to 2013 has increased, on the other hand, the price of plain bread in Serdang Bedagai Regency during 2011 to 2013 has decreased. It is recorded that the price of rice in 2012 was Rp. 7,488, - with a price of white bread of Rp. 5,000, while in 2012 the price of rice was Rp. 8,142, - and the price of white bread is Rp. 4000, while in 2013 the price of rice was Rp. 9,000, - and the price of white bread is Rp. 4,000.

In 2014, the price of rice decreased to $\mathrm{Rp} .8,132$ while the price of plain bread has increased to Rp. 5.083, -. At the end of 2015 the price of rice rose again to Rp. 9,262, while the price of plain bread fell to $\mathrm{Rp} .4,690$, -. The price of rice which continues to increase will have an impact on the pattern of consumption of the population towards rice itself. However, even though the price of rice continues to increase, the population of Serdang Bedagai Regency continues to consume it, because rice is the staple food. Even though its consumption patterns are changing.

One of the changes in people's consumption patterns is finding food to replace rice, especially at certain times when it feels appropriate to replace it. In this study, the assumption is that the replacement of staple food is plain bread as a substitute for breakfast (breakfast). Apart from being practical, plain bread is also efficient and easy to carry or consume without having to cook or process it again. White bread in this study is used as a substitute for rice as a substitute for rice.

According to Noeriati (2008), rice supply is also influenced by substituted goods. When the price of rice increases, based on consumer behavior it will switch to substitute goods. An increase in the price of substituted goods will have a positive effect on rice supply.

\section{RESEARCH METHOD}

This research is focused on analyzing the factors that influence the supply of rice in Serdang Bedagai Regency. Specifically, this study identifies the factors that influence offering rice (OR), namely area harvested, $(A H)$, rice price (RP), white bread price (BR) and rainfall (RF). This study uses secondary data from time series (time series) sourced from Statistics Indonesia (SI) Serdang Bedagai Regency and other sources during 2011 2015.

To determine the factors that affect the supply of rice in Serdang Bedagai Regency, the following model is used:

$$
P B=f(L P, H B, H R, C H)
$$

This equation with the specification of the econometric model after being logged is as follows:

$$
\log (O R)=\alpha_{0}+\alpha_{1} \log (A H)+\alpha_{2} \log (R P)+\alpha_{3} \log (B P)+\alpha_{4} \log (R F)+\mu_{1}
$$

Information:

OR: Offering Rice (Tons)

AH: Area Harvested (Hectares)

RP: Rice Price (Rupiah / Kg) 

BP: Bread Price (IDR)
RF: Rainfall (Day)
$\alpha_{0}$ : Constant / Intercept coefficient
$\alpha_{1} . \alpha_{2} . \alpha_{3} . \alpha_{4:}$ Regression coefficient
$\mu$ 1: Bully error

\section{RESULT AND DISCUSSION}

\section{Rice Production and Prices}

Rice production originating from rice production in Serdang Bedagai Regency during the period 2006 to 2015 has increased. Based on BPS data in 2006, rice production in Serdang Bedagai Regency was recorded at 364,889 tons, but experienced a significant decline in 2007 to reach the level of 342,432 tons. This is due to the many crop failures that have been experienced, in addition to the decreasing area of agricultural harvest which has changed the function of agricultural harvests to non-agricultural harvests.

In 2008, rice production in Serdang Bedagai Regency, rice production in Serdang Bedagai Regency, increased, although it was relatively low from the previous year, namely 344,401 tons, and again increased in 2009 to 347,743 tons. This increase occurred not because of the increase in agricultural harvested area, but due to the advancement of technology in the agricultural sector. In 2010 and 2011, rice production in Serdang Bedagai Regency decreased due to crop failure which was almost evenly distributed in all regions. It was recorded that rice production in 2010 was 364,876 tons and in 2011 was 328,344 tons.

In 2012 and 2013, rice production again experienced an increase due to the increase in the rice harvested area, also due to successful rice production in all rice plant centers. The increase in 2012 was 369,190 tonnes and 408,381 tonnes in 2013. The reduced harvest area for rice in 2014 was one of the causes for the decline in rice production to 370,604 tonnes, and again increased in 2015 due to the increase in harvested area. rice causes rice production to also increase in 2015 to 394,793 tons.

The development of rice production in Serdang Bedagai Regency during 2006-2015 is presented in the following figure:

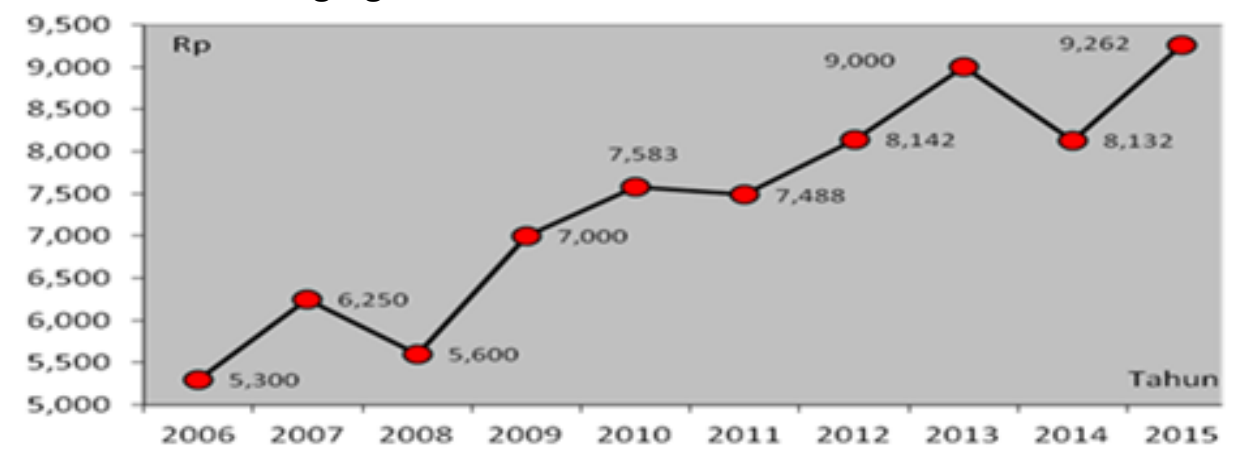

Figure 4: Development of Rice Prices in Serdang Bedagai District 2006 - 2015

Figure 5 shows the development of rice prices in Serdang Bedagai Regency during 2006

- 2015 in general experiencing an increase. It is recorded that the price of rice in Serdang

QE Journal | Vol.09 - No.01 - 15 
Bedagai Regency in 2006 was Rp. 5,300, - per kg and increased in 2007 to Rp. 6,250, per $\mathrm{kg}$. The global crisis that occurred in 2008 caused the government to import more rice from outside which resulted in a decrease in the price of rice in Serdang Bedagai Regency to Rp. 5,600, - per $\mathrm{Kg}$. In 2009, when the national economy was in a slump due to the global crisis, it had an impact on the regional economy. One of the significant impacts was the increase in prices of basic necessities, in this case the price of rice reaching $\mathrm{Rp}$. 7,000, - per kg and again increased in 2010 to $\mathrm{Rp} .7,583$, - per $\mathrm{kg}$. Despite the decline in rice prices in 2011 to Rp. 7,488 per kg but increased again in 2012 to Rp. 8,342, - per kg and in the amount of Rp. 9,000, - per kg in 2013. Meanwhile, in 2014 the price of rice in Serdang Bedagai Regency fell again to Rp. 8,132, - per kg and again increased in 2015 to Rp. 9,262, - per kg.

\section{Area Harvested}

The area harvested for rice is strongly influenced by the harvest area used for rice crops and economic activities as well as the needs of the population itself, the higher the economic activity and the higher the population growth rate the higher the need for harvest use. The higher the need for harvest for non-agricultural activities, the narrower the harvest for agriculture itself.

From Statistics Indonesia data (2016), the rice harvested area in Serdang Bedagai Regency in 2015 was 71,748 hectares, a decrease compared to 2006, which was 75,769 hectares. The decrease in harvested area was caused by the decreasing harvested area for rice farming. The decline in agricultural harvested area has a negative impact on the harvested area for rice.

The harvested area for rice in Serdang Bedagai Regency, North Sumatra Province during 2006 to 2015 is presented in the following figure:

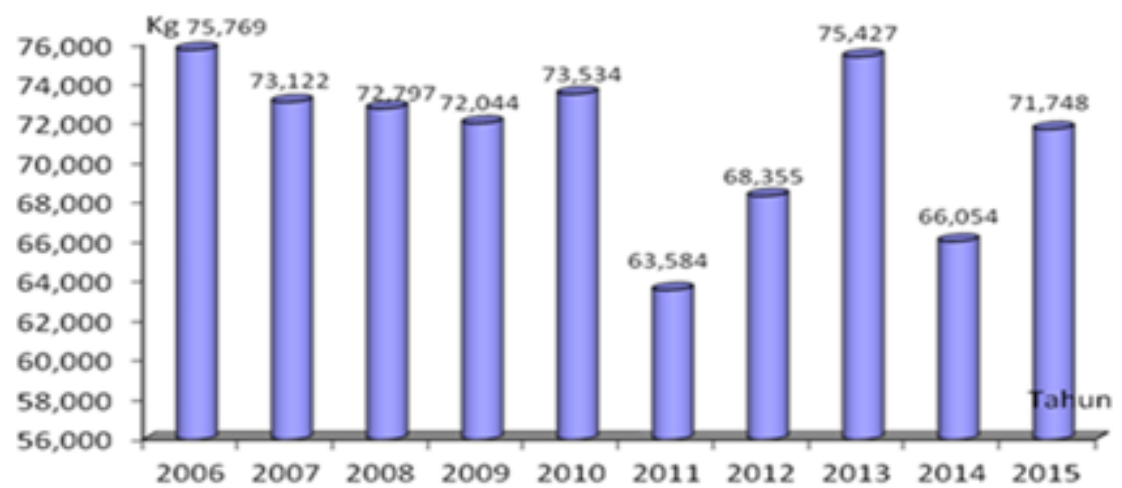

Figure 5: Development of Harvested Area in Serdang Bedagai District 2006 - 2015 Source: Statistics Indonesia Serdang Bedagai Regency (2007-2016)

Figure 6 shows that during 2006 to 2015 the harvested area in Serdang Bedagai Regency, North Sumatra Province, in general, showed a decrease in line with the increasing population and the need for non-agricultural crops. It is recorded that in 2006 the harvested area reached 75,769 ha which was allocated for rice harvesting. From 2007 to 2009 the harvested area decreased to 73,122 ha in 2007 , amounted to 72,797 ha in 
2008 and became 72,044 ha in 2009 . With the increasing harvest area marked by higher rice production, in 2010 the harvest area used for the agricultural sector amounted to 73,534 ha. In 2011, the harvested area for the agricultural sector decreased quite significantly. This is due to the decreasing area of land for rice plants or the area of agricultural land changing into non-agricultural land, especially for rice plants. amounting to 63,584 ha. The harvested area increased again in 2012 to 2013 due to the fact that the area of non-rice agricultural land turned into rice farming land. It was recorded that the harvested area in 2012 was 68,355 ha and 75,427 ha in 2013. In 2014, the harvested area for rice again decreased to 66,054 ha and increased again at the end of 2015 to be 71,748 ha.

\section{White Bread Price Development}

White bread is one of the manufactured commodities which is a snack containing carbohydrates and as a substitute for rice, especially foods labeled instant (fast food). This function places the position of plain bread in diversifying consumption and reducing dependence on rice as the staple food. The retail price of plain bread in Serdang Bedagai Regency from 2006 to 2015 based on data from Statistics Indonesia shows an increasing number. Where in 2006 the price of plain bread in Serdang Bedagai Regency was Rp. 3,500, -, in 2007 amounting to Rp. 4,000, -. Meanwhile, in 2008 to 2010 each amounted to Rp. 2,000, - in 2008 and amounting to Rp. 2,500, -. In 2009 and 2010.

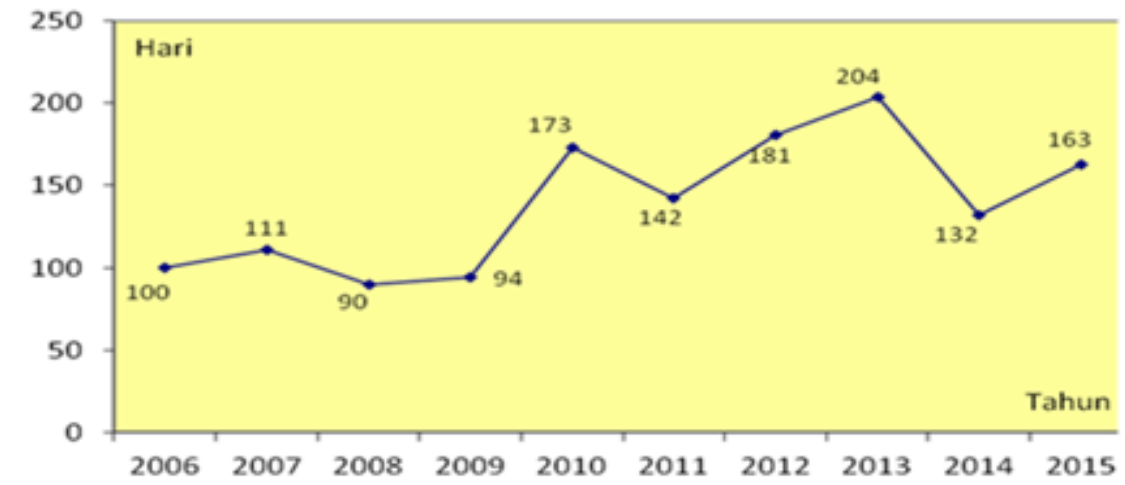

Figure 6: White Bread Price Development in Serdang Bedagai 2006 - 2015 Source: Statistics Indonesia Serdang Bedagai Regency (2007-2016)

From Figure 7, it can be seen that the price of plain bread in Serdang Bedagai Regency in 2011 experienced a significant increase compared to the price of plain bread in the previous year. It was recorded that the price of plain bread in 2011 was Rp. 5,000, - and again decreased to Rp. 4,000, - in 2012 and 2013. Meanwhile in 2014 the price of plain bread in Serdang Regency increased again to Rp. 5.083, -. Until the end of 2015, the price of plain bread in Serdang Bedagai Regency reached Rp. 4,690, -.

\section{Rainfall}

The intensity of rainfall in Serdang Bedagai Regency, North Sumatra Province based on BMK Polonia Medan data has relatively changed although it is not significant in several years. 


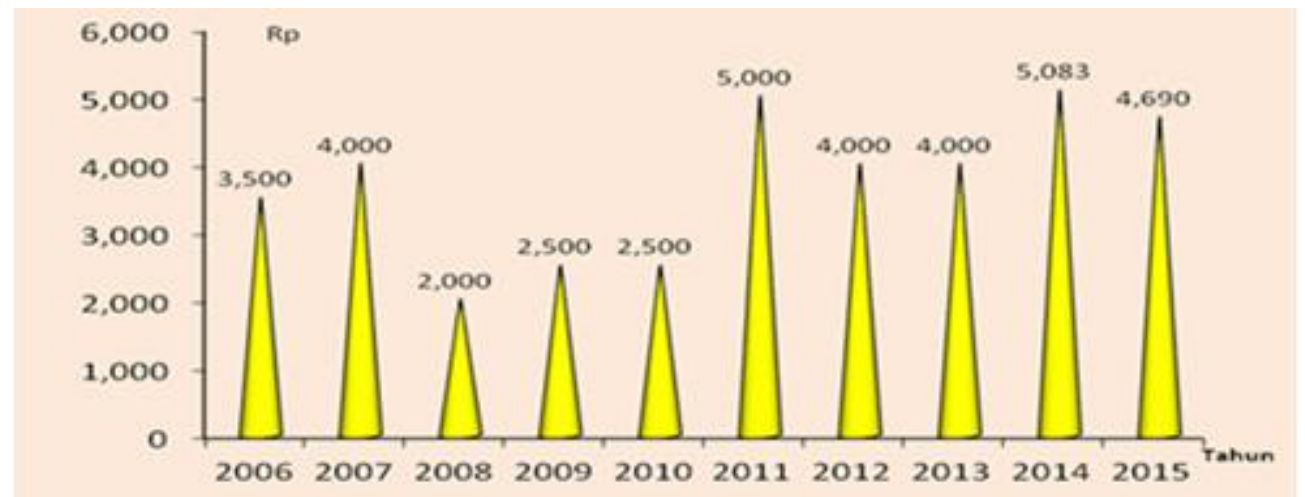

Figure 7: Rainfall Intensity in Serdang Bedagai District, 2006 - 2015 Source: Statistics Indonesia Serdang Bedagai Regency (2007-2016)

Figure 8 shows that the rainfall that occurred in North Sumatra during 2006 to 2015 fluctuated and in general showed a shift in seasonal patterns that occurred. In 2006 the intensity of rainfall reached 100 days, increased to 111 days in 2007 and decreased again to 90 days in 2008. Meanwhile in 2009 the intensity of rainfall again increased to 94 days. In 2010, the rainfall intensity pattern in Serdang Bedagai Regency increased significantly to 173 days. In 2011 this pattern shifted again, where the intensity of the rainfall was 142 days, but again increased in 2012 and 2013 to 181 days in 2012 and 204 days in 2013. In 2014 the rainfall was 132 days and at the end of 2015 Rainfall as much as 163 days.

\section{Statistic test}

Statistical analysis is used to see the validation of the model used in this study.

Table 1: Estimation Results of the Offering Rice Model (OR)

Dependent Variable: LOG(PB)

Method: Least Squares

Date: 11/06/16 Time: 14:08

Sample: 20062015

Included observations: 10

\begin{tabular}{|c|c|c|c|c|}
\hline & Coefficient & Std. Error & t-Statistic & Prob. \\
\hline $\mathrm{C}$ & 0.436555 & 2.772801 & 0.157442 & 0.8811 \\
\hline LOG(LP) & 0.877509 & 0.222737 & 3.939668 & 0.0110 \\
\hline $\operatorname{LOG}(\mathrm{HB})$ & 0.227667 & 0.074433 & 3.058681 & 0.0281 \\
\hline LOG(HR) & 0.057164 & 0.045980 & 1.243224 & 0.2689 \\
\hline $\operatorname{LOG}(\mathrm{CH})$ & 0.014221 & 0.046923 & 0.303074 & 0.7740 \\
\hline R-squared & 0.811732 & \multicolumn{2}{|c|}{ Mean dependent var } & 12.80163 \\
\hline Adjusted R-squared & 0.661118 & \multicolumn{2}{|c|}{ S.D. dependent var } & 0.066533 \\
\hline S.E. of regression & 0.038731 & \multicolumn{2}{|c|}{ Akaike info criterion } & -3.357483 \\
\hline Sum squared resid & 0.007501 & \multicolumn{2}{|c|}{ Schwarz criterion } & -3.206191 \\
\hline Log likelihood & 21.78742 & \multicolumn{2}{|c|}{ Hannan-Quinn criter. } & -3.523451 \\
\hline F-statistic & 5.389476 & \multicolumn{2}{|c|}{ Durbin-Watson stat } & 2.552541 \\
\hline Prob(F-statistic) & 0.046589 & & & \\
\hline
\end{tabular}


The results of the regression analysis of offering rice (OR) can be written in a linear equation as follows:

\section{$\log (O R)=0.436555+0.877509 * \log (A H)+0.227667 * \log (R P)+0.057164 * \log (B P)+$ $0.014221 * \log (R F)$}

The estimation results of Offering Rice (OR), the independent variable Area Harvested $(\mathrm{AH})$ and Rice Price (RP) have a positive and significant effect at $\alpha=5$ percent of offering rice (OR) in Serdang Bedagai Regency, North Sumatra Province, which also implies that when harvested area and the price of rice increases, so the supply of rice will also increase. Conversely, if the harvest area and the price of rice go down, the rice supply will decrease. While the variable of bread price (BP) and rainfall (RF) has a positive but insignificant effect on rice supply (PB) in Serdang Bedagai Regency, North Sumatra Province at $\alpha=5$ percent.

Statistical testing was carried out on the regression model results. The statistical testing includes testing the t-statistic, F-statistic, and R2 value.

\section{Statistical $\mathbf{t}$ test (Partial Test)}

The t-test or partial test is done to see the effect of the independent variable on the dependent variable partially or one by one. From the results of the estimation model for offering rice $(O R)$, the $t$ value for each variable is obtained as follows:

1. AH with $t_{\text {count }}=3.939668$ with a probability level of 0.0110 . This shows that the probability value is smaller than $\alpha=0.05$ so that the variable $\mathrm{AH}$ is significant at the $95 \%$ level of confidence that will positively affect the rice supply (OR), which means that if there is an increase in harvested area by 1 percent, then the rice supply (OR) will increase by the coefficient of 0.88 percent, cateris paribus.

2. RP with tcount $=3.058681$ with a probability level of 0.0281 . This shows that the probability value is greater than $\alpha=0.05$, so that the RP significance variable affects the rice supply (OR) with a $95 \%$ confidence level.

3. BP with tcount $=1.243224$ with a probability level of 0.2689 . This indicates that the probability value is greater than $\alpha=0.05$, so that the BP variable is not significant at the $95 \%$ confidence level.

4. RF with tcount $=0.303074$ with a probability level of 0.7740 . This shows that the probability value is greater than $\alpha=0.05$, so that the RF variable is not significant at the $95 \%$ confidence level.

\section{Statistical F Test (Simultaneous Test)}

The F-test or the draw test is carried out to see the effect of the independent variables simultaneously or together on the dependent variable. From the results of the estimated model for rice supply, the calculated $F$ value is 5.389476 with a probability level of 0.046589 . This shows that the independent variables for rice supply, namely harvested area, rice price and fresh bread price, and rainfall simultaneously and significantly influence the dependent variable, namely rice supply at a level of confidence of $95 \%$. 


\section{Determination Coefficient Test $\left(\mathbf{R}^{2}\right)$}

The coefficient of determination $\left(R^{2}\right)$ test is used to see how much variation in the independent variable can explain the dependent variable. From the estimation results for the rice supply, the $R^{2}$ value is 0.811732 . This means that $81.17 \%$ of the rice supply variable can be explained by the variables $A H, R P, B P$ and $R F$. While the remaining $18.83 \%$ is explained by other variables outside the model

\section{CONCLUSIONS AND RECOMMENDATIONS}

\section{Conclusion}

Based on the regression results of the model studied, the following conclusions can be drawn:

1. From the coefficient of determination in the estimation results, offering rice (OR) in Serdang Bedagai Regency, North Sumatra Province can be explained by the variables of harvested area, rice price and fresh bread price and rainfall can be explained by the model used.

2. The variables used to explain the rice supply variable offering rice (OR) show the direction of influence in accordance with the hypothesis. Harvested area and rice prices have a positive and significant effect on offering rice (OR), while the price of plain bread and rainfall have a positive but insignificant effect on offering rice (OR) Serdang Bedagai Regency, North Sumatra Province.

3. The magnitude of the coefficient values of the variables that explain offering rice $(\mathrm{OR})$, the largest is the harvest area variable, followed by rice price, plain bread price and rainfall variables, respectively.

\section{Suggestion}

1. It is recommended that the government of Serdang Bedagai Regency, North Sumatra Province be able to maintain adequate rice consumption in the region by making regulations, one of which is to use idle lands to be used as agricultural land, especially rice plants. Utilizing idle land into productive land, especially cultivating it as paddy field, will have a positive impact on rice production. The estimation results show that the harvested area has a very large effect on production.

2. The government of Serdang Bedagai Regency, North Sumatra Province, should maintain the stability of the prices of basic necessities, especially rice. Regulations that support achieving rice price stability by making regulations that are not burdensome to farmers and traders and taking firm action against hoarders and speculators who harm rice farmers.

3. The government of Serdang Bedagai Regency, North Sumatra Province, should start socializing the substitute for rice staple food other than plain bread which in this study does not significantly affect rice supply. The substitute food for rice can be in the form of corn, yams and others which contain nutrients similar to rice, so that the staple food of the community does not depend solely on rice.

\section{REFERENCES}

QE Journal | Vol.09 - No.01 - 20 
AAK, 1990. "Budi Daya Tanaman Padi". Kianisius, Yogyakarta.

Akbar, Arief RM. 2002. "Model Simulasi Penyediaan Kebutuhan Beras Nasional". Makalah Pengantar Falsafah Sains. LPB. Bogor.

Arsyad, lincolin, 2008, "Ekonomi Manajerial-Ekonomi Mikro Terapan untuk Manajemen Bisnis", BPEF, Yogyakarta.

Eachern Mc William A. 2001. "Ekonomi Mikro Pendekatan Konteporer", Edisi Pertama Salemba Empat. Jakarta.

Firdaus, M. 2008. “Manajemen Agribisnis". Bumi Aksara. Jakarta.

Irawan, 2005, "Analisis Ketersediaan Beras Nnasional : Suatu Kajian Simulasi Pendekatan System Dinamis". Jurnal Prosiding Multi Fungsi Pertanian

Malian, Mardianto dan Ariani, 2004. "Faktor-Faktor Yang Mempengaruhi Produksi, Konsumsi, dan Harga Beras serta Inflasi Bahan Makanan", Jurnal Agro Ekonomi, Volume 22 No. 2.

Mankiw, N. G, 2000. "Pengantar Ekonomi", Jilid I. Erlangga, Jakarta. Alih bahasa oleh Drs. Haris Munandar, MA

Nur, Muhammad. 2009. "Tingkat Pengaruh Berbagai Factor Terhadap Produksi Padi Sawah di Kecamatan Ladongi Kabupaten Kolaka Sulawesi Tenggara", Jurnal Sumber daya Insani. Universitas Muhammadiyah Kediri.

Pappas James, L dan Mark Hirschey, 1995. "Ekonomi Managerial".Bina Rupa Aksara Jakarta.

Pudjadi, Tri danHarisno, 2007. "Model Pengelolaan Stok dan Konsumsi Beras Berbasis Decision Support System pada Era Otonomi Daerah (OTDA)". Makalah Seminar Nasional Aplikasi Teknologi Informasi (SNATI 2007), Yogyakarta, 16 Juni.

Saragih, B.2001. "Pembangunan Pertanian 2001-2004", Departemen Pertanian. Jakarta.

Situmorang, MT. 2005. "Analisis Faktor-faktor yang mempengaruhi produksi dan impor beras Indonesia", Skripsi. Program Studi Ekonomi Partanian dan Sumber daya .Fakultas Pertanian. Institut Pertanian Bogor, Bogor.

Soekartawi. 2002. "Prinsip Dasar Ekonomi Pertanian (Teori dan Aplikasi"). Raja Grafindo Persada, Jakarta.

Sudaryanto, T.B. Rahmandan S. Bachri. 2000. "Arah Kebijakan Disttribusi/ Perdagangan Beras dalam Mendukung Ketahanan Pangan: Aspek Perdagangan Luar Negeri". Sinar Harapan, Jakarta.

Sukirno Sadono, 2005, "Pengantar Teori Mikro Ekonomi". PT Raja Grafindo Persada Jakarta.

Suryana, A danHermanto. 2003. "Kebijakan ekonomi Perberasan Nasional. Ekonomi Padi dan Beras Indonesia". Badan Penelitian dan Pengembangan Pertanian Departemen Pertanian. Jakarta. 
Susanto, U, 2004, "Retrospek Dan Prospek Peranan Pemuliaan Tanaman Padi Dalam Dinamika Perkembangan Zaman". Program Pasca sarjana Institut Pertanian Bogor.

Sunani, Nani. 2009. "Analisis faktor-faktor yang mempengaruhi produksi dan konsumsi beras di Kabupaten Siak, Riau". Institut Pertanian Bogor.

Wijaya Karya Jaya, 2012. "Pengaruh persediaan beras, produksi beras dan harga beras terhadap ketahanan pangan kabupaten/kota di Jawa Tengah tahun 20082010".Jurnal Ekonomi Pembangunan, Fakultas Ekonomi, Universitas Negeri Semarang, Indonesia.

Yanidah, Silviana. 2012. "Analisis faktor-faktor yang mempengaruhi ketersediaan beras di Deli Serdang", .Jurnal Pertanian Universitas Sumatera Utara 